OPEN ACCESS

Edited and reviewed by: Annette Cameron Broderick, University of Exeter, United Kingdom

${ }^{*}$ Correspondence: Annette Breckwoldt annette.breckwoldt@awi.de

Specialty section: This article was submitted to Marine Conservation and Sustainability,

a section of the journal Frontiers in Marine Science

Received: 23 January 2018 Accepted: 09 February 2018 Published: 22 February 2018

Citation:

Breckwoldt A, Ratter BMW and Wang W-C (2018) Editorial: Fishing for Human Perceptions in Coastal and Island Marine Resource Use Systems.

Front. Mar. Sci. 5:62.

doi: 10.3389/fmars.2018.00062

\section{Editorial: Fishing for Human Perceptions in Coastal and Island Marine Resource Use Systems}

\author{
Annette Breckwoldt ${ }^{1 *}$, Beate M. W. Ratter ${ }^{2}$ and Wen-Cheng Wang ${ }^{3}$ \\ ${ }^{1}$ Alfred-Wegener Institute, Helmholtz Centre for Polar and Marine Research (AWI), Bremerhaven, Germany, ${ }^{2}$ Department of \\ Human Dimensions in Coastal Areas, Institute of Coastal Research, Helmholtz Zentrum, Geesthacht, Germany, ${ }^{3}$ Department \\ of Geography, National Taiwan Normal University, Taipei, Taiwan
}

Keywords: perceptions, marine resource use, qualitative research, decision-making process, coastal communities, stakeholder interactions

\section{Editorial on the Research Topic}

\section{Fishing for Human Perceptions in Coastal and Island Marine Resource Use Systems}

This Research Topic focuses on bringing together human perceptions and activities for sustainable coastal and island marine resource use systems. The initial idea of this topic formed by an increasing awareness that human perceptions, individual decision-making and (pro-) environmental behavior are much closer connected than so far acknowledged by academia and the scientific research community in general. Management and governance of (large and small-scale) coastal marine resource use systems function in highly complex social and ecological environments, which are culturally embedded, value-driven, economically interest-led and politically biased. Local action is not least framed by mental contribution and attribution of coasts as places for living, recreation and resource use. Mental constructs of coasts and marine resources as valuable areas can, in some cases, lead to the protection and preservation by initiatives of collective action, and in other cases, it is difficult to mobilize local communities to adapt and to engage in environmental management strategies (Ratter et al., 2016). Management processes therefore ought to integrate multiple perspectives as well as perception-driven standpoints on the individual as well as the decision-makers' levels. Consequently, the analysis of perceptions has developed not only as part of philosophy and psychology but also of environmental science, anthropology and human geography. It encompasses intuitions, values, attitudes, thoughts, mind-sets, place attachments and sense of place. All of these influence human behavior and action, and can be collected or are available within the respective marine resource use system. Often, these systems support the livelihood of a large part of the local population.

The 12 articles in this Research Topic have been authored by 48 researchers from 10 different countries, presenting critical insights from across the globe-from small islands in the South Pacific to Sri Lanka, China, South Africa, Norway or Uzbekistan. The institutions from the submitting authors range from Universities to think tanks, to research centers, or NonGovernmental Organizations-and the authors themselves were at very different stages in their career (from very early to senior researcher). The diversity of the professional backgrounds (Geography, Environmental Psychology, Ecology, Sociology, and Anthropology) shows in essence that researching perceptions in (not only marine) natural resource use systems does not have 
a distinctive disciplinary boundary. All of the articles are interdisciplinary, and many also have transdisciplinary approaches, employing mainly qualitative approaches (partly in combination with quantitative methods), to face the challenge of uncovering, exploring and analyzing the perceptions of a variety of stakeholders in marine resource use systems, from traders to conservation managers.

The stories told by these articles are indeed just as diverse, from cases of individual meaning-making and highlighting the power of individual perceptions (Beyerl et al.; Siriwardane-de Zoysa and Hornidge) to collective action around the status of fishery resources (Leenhardt et al.) or the persistence of destructive fishing practices (Katikiro and Mahenge). Some of the articles showcase methods for perception research, such as the Q-methodology (Hagan and Williams) or stakeholderinformed modeling (Koenigstein et al.), allowing to quantify these "qualitative subjectivities" in ways readable for machines as well as human decision-makers. All articles have a critically high level of contextuality, and show how perceptions can have an impact on decision-making processes within the science-stakeholder "entanglement." The roles of perceptions in understanding and optimizing the usefulness of management measures, conservation projects and bridging organizations for better and more sustainable conservation solutions are among the less hidden examples (Berdej and Armitage; Beyerl et al.; Hagan and Williams). Understanding aspects of leadershipperceived and factual-responsibilities and legitimacies (of persons or activities and functions; Katikiro and Mahenge; Rohe et al.; Sutton and Rudd), very clearly show the requirement of in-depth research on perceptions. Oftentimes, these aspects of leadership, the complexities and confusions linked to it and individual decisions (Gorris), are often based on very tangible/conventional matters such as economic benefit (Fabinyi et al.; Gorris), but are also tightly linked to aspects of transparency, lack of trust (including perceived and real threats; Katikiro and Mahenge), and enforcement (Gorris; Rohe et al.). One aspect that may not be underestimated, but still underresearched, is the role of local (individual and subjective as they may be) perceptions on the transformation and governance of larger coastal areas (Katikiro and Mahenge; Kitolelei and Sato) and even more distant environments (Fabinyi et al.). The articles also show that a strong perception-based impact exists across all levels of such processes, from the individual resource-user, to larger societal and professional networks.

This Research Topic show-cases the need for a larger recognition in academia that management and governance are not only about mediating between resource use conflicts or

\section{REFERENCES}

Bennett, N. J. (2016). Using perceptions as evidence to improve conservation and environmental management. Conserv. Biol. 30, 582-592. doi: $10.1111 /$ cobi.12681

Bennett, N. J., and Dearden, P. (2014). Why local people do not support conservation: community perceptions of marine protected area livelihood establishing marine protected areas. Moreover, they deal with people and their ideas, knowledge and perceptions (Bennett and Dearden, 2014; Wyles et al., 2014; Bennett, 2016; Gelcich and O'Keeffe, 2016; Ratter et al., 2016; Hoshino et al., 2017). And understanding the related decision-making processes on multiple scales and levels means indeed more than economically assessing the available marine resources or existing threats to the associated system. The editors trust that this Research Topic adds substance and visibility to the growing body of research and literature that presents an integration of perceptions of island, coastal and inland residents, local and regional stakeholder groups, as well as resource and environmental managers and decisionmakers.

In conclusion-by acknowledging the importance of the individual perspective and interest-led personal views, it becomes obvious how valuable and important these sources of information are for coastal research. An increase of research effort and academic discourse spent on the link between perceptions and behavior in marine resource use systems is thus both timely and needed, and is in fact observable by the increasing number of perception-related publications. The challenges to find, to analyse and to publish studies on perceptions remains, but by raising their academic profile, authors of articles such as published in this Research Topic should find a different, more visible platform-for a publication- and dialogue-based sharing of questions and findings. By fishing for a diversity of inspiring and comprehensive contributions on the link between perceptions and behavior, this Research Topic shall critically enlighten the discourse and applicability of such research for finding sustainable, locally identified, anchored and integrated marine resource use pathways.

\section{AUTHOR CONTRIBUTIONS}

All authors listed, have made substantial, direct and intellectual contribution to the work, and approved it for publication.

\section{ACKNOWLEDGMENTS}

We would like to express our sincere gratitude to all peerreviewers for their incredible work in effort and time spent to guide these contributions to publication.

We would also like to thank our colleague Prof. Hans von Storch for joining us in this effort as a valuable advisor.

Finally, we would like to thank the entire editorial team at Frontiers in Marine Science for their accurate, fast and always friendly input, support and feedback. 
resource management in the Kei Islands, Indonesia. Front. Mar. Sci. 4:141. doi: 10.3389/fmars.2017.00141

Ratter, B., Petzold, J., and Sinane, K. (2016). Considering the locals. Coastal construction and destruction in times of climate change on Anjouan, Comoros. Nat. Resour. Forum 40, 112-126. doi: 10.1111/1477-8947. 12102

Wyles, K. J., Pahl, S., and Thompson, R. C. (2014). Perceived risks and benefits of recreational visits to the marine environment: integrating impacts on the environment and impacts on the visitor. Ocean Coast. Manage. 88, 53-63. doi: 10.1016/j.ocecoaman.2013. 10.005
Conflict of Interest Statement: The authors declare that the research was conducted in the absence of any commercial or financial relationships that could be construed as a potential conflict of interest.

Copyright (c) 2018 Breckwoldt, Ratter and Wang. This is an open-access article distributed under the terms of the Creative Commons Attribution License (CC $B Y)$. The use, distribution or reproduction in other forums is permitted, provided the original author(s) and the copyright owner are credited and that the original publication in this journal is cited, in accordance with accepted academic practice. No use, distribution or reproduction is permitted which does not comply with these terms. 